\title{
Kehadiran Kristiani dalam Politik: Rekonstruksi Teologi Misi Tentang Peran Kekristenan dalam Ruang Publik Politis di indonesia
}

\author{
Grets Janialdi Apner \\ Sekolah Tinggi Filsafat Theologia Jakarta \\ gretsaldi@gmail.com
}

\begin{abstract}
Abstrak
Artikel ini menawarkan sebuah rekonstruksi teologi misi terkait kehadiran gereja dalam ruang publik politik sebagai wujud penginjilan. Saya menggunakan metode kritik sosiologis-historis yang diimbangi dengan perspektif misiologi terkait ruang publik, politik dan penginjilan. Pembahasan dimulai dengan konsep ruang publik dan politik sebagai landasan kritik terhadap model kehadiran agama dalam ruang publik politik di Indonesia. Kemudian dilanjutkan dengan teori penginjilan sebagai kehadiran Kristiani yang membawa damai dan tidak bersifat dominan di ruang publik. Semuanya saya lakukan untuk membuktikan bahwa gereja, melalui umat, dapat dan perlu berperan aktif dalam ruang publik politis sebagai wujud penginjilan dalam politik.
\end{abstract}

Kata Kunci: penginjilan; ruang publik; politik; kehadiran kristiani.

\begin{abstract}
This article offers a theological reconstruction of church presence in political public sphere as an evangelism. I use sociological-historical criticism that makes up for a missiological perspective on public sphere as a basis for critique of the model of religious presence in the political public sphere in Indonesia. The followed by the evangelism theory as a peaceful and undominant Christian presence in public sphere. It is to prove that the church, through the people, can and will need to take an active role I political public sphere as and evangelism in politics.
\end{abstract}

Keywords: evangelism; public sphere; politics; Christian presence. 


\section{PENDAHULUAN}

Keberadaan agama di dalam sebuah negara akan menemui dua pilihan, yaitu berdampak atau tidak berdampak. Artinya, agama akan selalu menghadapi pengambilan keputusan untuk berpartisipasi secara aktif atau bersikap pasif terhadap dan/atau di dalam negara tersebut. Kondisi ini muncul karena agama berada di dalam sebuah ruang lingkup yang lebih luas dari dirinya sendiri, yakni ruang publik. Ruang itulah yang mempertemukan komunitas agama, termasuk gereja dan komunitas Kristen, dengan seluruh individu dan paham di luar gereja yang memiliki sedikit-banyak perbedaan dengannya. Pada situasi tersebut gereja perlu untuk memberikan respons agar tidak terasing atau bahkan menjadi lawan dari seluruh hal yang berada di luar dirinya sendiri (Trisna, 2016).

Masalah akan muncul apabila gereja sebagai wujud organik dari agama Kristen justru memilih untuk tidak memberikan respons dalam ruang publik, salah satunya politik. Setidaknya hal itulah yang disadari oleh Julianus Mojau bahwa kebanyakan umat Kristen di
Indonesia menuntut gereja untuk bersikap netral dalam politik bangsa dan tidak mau menganggap gereja sebagai komunitas iman politis. Gereja seolah-olah tidak memiliki nilai politis dan membuatnya justru semakin sulit untuk berdampak terhadap persoalan-persoalan sosial. Namun, apakah benar bahwa gereja tidak politis sehingga gereja dilarang untuk bersikap dalam lingkup politik praktis?

Melalui makalah ini saya akan membuktikan bahwa keterlibatan politis dari gereja merupakan wujud eksistensi Kekristenan kontemporer di dalam ruang publik yang juga termasuk bentuk keterlibatan gereja dalam karya missio Dei.

\section{METODE PENELIAN}

Penulis menggunakan metode penelitian kepustakaan dengan merujuk pada sumber-sumber primer maupun sekunder untuk menelusuri pemikiran dan konsep-konsep teologis yang sesuai dengan topik penelitian (Chandra, 2019). Pembahasan dimulai dengan penjelasan perihal Ruang Publik, Politik dan Identitas dalam Keberagaman. Kemudian dilanjutkan dengan rekosntruksi keterlibatan 
gereja dalam ruang publik politis sebagai wujud penginjilan dalam politik. Penginjilan dalam politik bukanlah sebuah usaha untuk menjadikan Kekristenan sebagai identitas yang mendominasi identitas lain yang ada dalam kemajemukan konteks Indonesia. Justru, penginjilan dalam politik menjadi cara bagi Kekristenan (gereja) di Indonesia untuk mengejawantahkan dan menghadirkan karakter misionalnya di ruang publik.

\section{HASIL DAN PEMBAHASAN}

Ruang publik menurut Jurgen Habermas adalah (Habermas 1997, 105):

'By 'public sphere' we mean first of all a domain or our social life which such a thing as public opinion can be formed. Access to the public sphere is open in principle to all citizens. A portion of the public sphere is constituted in every conversation in which private persons come together to form a public."

Definisi Habermas tersebut telah memberikan penekanan yang cukup jelas bahwa ruang publik merupakan sebuah lingkup, ruang kehidupan sosial yang terbuka bagi seluruh rakyat dan yang di dalamnya telah terjadi proses pembentukan opini secara komunal. Setiap individu memiliki peran untuk turut membentuk kehidupan komunal dimana ia hidup, beraktivitas dan berkarya. Pernyataan Habermas juga menunjukkan bahwa proses tersebut dapat dilakukan termasuk dihambat, bahkan dibatalkan oleh setiap orang yang ada di dalam kehidupan sosial tersebut karena setiap individu memiliki akses yang seimbang dengan individu lainnya untuk menyampaikan opini pribadinya kepada lingkungan yang lebih besar dari diri atau kelompoknya sendiri. Konsep ruang publik telah menjadi kesempatan bagi setiap individu untuk menyadari bahwa dirinya memiliki peran yang penting dalam pembentukan kultur publik, kebijakan publik, dan dalam proses menjalankan negara (Mckee 2005, 105).

Pembentukan opini dalam lingkup komunal itu pun akan sangat dipengaruhi dengan proses komunikasi yang muncul di dalamnya. Bagi Habermas, pembentukan opini yang efektif dalam jumlah publik yang besar akan membutuhkan proses komunikasi dengna makna-makna penyebaran dan pengaruh yang besar juga (Habermas 1997, 105). Salah satu contoh proses pembentukan opini 
yang efektif untuk menyebarkan dan berpengaruh dalam ruang publik adalah media, entah itu cetak maupun audio-visual. Pembentukan opini dalam ruang publik ini pun menjadi proses yang penting dan tidak dapat dilakukan sekedarnya hingga terkesan taken for granted. Salah satu isu dalam ruang publik yang juga merupakan hasil dari pembentukan opini komunal dan perlu mendapatkan sikap kritis adalah nasionalisme agar tidak menjadi produk komunal yang taken for granted atau mempertahankan status quo.

Di dalam sebuah negara-bangsa seperti Indonesia dengan tingkat keberagaman yang tinggi muncul sebuah slogan untuk menjunjung nasionalisme pada setiap penduduknya, misalnya 'NKRI (Negara Kesatuan Republik Indonesia) Harga Mati'. Bagi saya, model-model pembentukan opini publik semacam ini memiliki kelemahan karena dapat berujung hanya sebatas kesatuan politik sebagai sebuah polis. Kelemahan tersebut pun akan menimbulkan sejumlah pertanyaan konseptual dan praktikal yang juga berujung pada munculnya gerakan-gerakan separatis atau radikal untuk melepaskan diri dari negara Indonesia. Leonardus Samosir pun beranggapan bahwa diperlukan dasar yang lebih kuat, yang melampaui fakta historis perjuangan dalam kemerdekaan dan kesatuan ideologis untuk mengikat penduduk Indonesia sebagai sebuah negara-bangsa (Samosir 2009, 255). Dia mengkritik penggunaan slogan 'satu Indonesia' yang berusaha meningkatkan kesatuan bangsa padahal telah mengesampingkan realitas keberagaman yang ada di negara ini. Sejarah memang telah menunjukkan bahwa negara Indonesia merdeka dan dibangun diatas dasar perjuangan bersama dari seluruh individu yang ada di wilayah Indonesia. Namun, persoalannya saat ini adalah kita tidak sedang melawan penjajahan atau menghadapi kolonilalisme. Inilah yang membuat model pembentukan nasionalisme yang hanya didasari oleh historisitas perjuangan dengan tujuan memupuk kesatuan bangsa hanya merupakan wujud penyatuan dalam konsep atau bahasa politik belaka. Kritik Samosir ingin menunjukkan adanya jarak emosional maupun ideologis yang 
tidak dialami oleh generasi-generasi sekarang untuk membentuk nasionalisme di Indonesia. Saya pikir, kritik tersebut adalah baik untuk mengkritisi proses pembentukan nasionalisme tanpa justru membuat penduduk Indonesia menganggap rendah fakta dan proses historis kemerdekaan Indonesia.

Indonesia sebagai sebuah negarabangsa memiliki sebuah produk identitas komunal yang dapat ditumbuhkembangkan dalam ruang publik Indonesia, yaitu Pancasila. Keberadaan sila ketiga telah menolong kita untuk menyadari bahwa frasa "bangsa Indonesia" dalam sila ketiga itu dapat berperan sebagai pemersatu bangsa. Dasar yang digunakan Presiden Soekarno adalah pengertian bangsa sebagai sekumpulan manusia yang berbedabeda bahasa, agama, suku dan turunannya namun memiliki kehendak untuk hidup bersama (Samosir 2009, 258). Bagi saya nilai ini lebih dari sebuah kesatuan sebagai sebuah konsep politik, melainkan sudah merupakan pembentukan identitas publik yang menggugah semangat kekeluargaan dan nilai hidup komunal yang saling menghargai dan menjaga. Namun, pernyataan saya barusan tidak bermaksud untuk merendahkan kualitas aspek politik dalam ruang publik. Justru, seperti penilaian Habermas, politik pun dapat menjadi proses komunikasi yang juga memiliki pengaruh dan efektifitas yang besar dalam ruang publik. Dia menyebutnya sebagai 'ruang publik politis'.

\section{Politik Sebagai Ruang Publik}

Politik, menurut Habermas, menjadi sebuah proses komunikasi dan pembentukan opini dalam ruang publik ketika kita membicarakan tentang berpraktik di dalam negara. Politik juga merupakan pewujudan pengetahuan yang baik tentang kehidupan oleh warga negara untuk dilakukan dalam ruang publik (Koten 2010, 134). Secara khusus Habermas memberikan penekanan mengenai perbedaan antara kuasa negara, yang di dalamnya terdapat institusiinstitusi yang dibentuk oleh publik, dengan ruang publik politis. Negara (pemerintah dan segala institusi di dalam negara tersebut) bukanlah ruang publik politis. Kuasa negara merupakan hasil dari ruang publik politis yang dibentuk oleh publik di dalamnya yang bersepakat untuk 
meminjamkan kuasa tersebut kepada para institusi untuk menjalankan tugas, yakni pemeliharaan publik (Habermas 1997, 105).

Habermas juga menegaskan bahwa publik perlu memberikan suara atau opininya dalam ruang publik politis untuk mengkritisi dan mengendalikan otoritas negara melalui pemerintah agar negara dapat menjalankan perannya sebagaimana mestinya (Habermas 1997, 105). Biasanya semua idealisme kerja pemerintah tersebut muncul pada masa-masa kampanye. Berdasarkan penegasan Habermas tersebut kita pun mendapati bahwa merupakan sebuah proses yang penting bagi masyarakat untuk menikmati proses pemilu, karena melalui dan berdasarkan pemilumasyarakat dapat membuat opininya untuk mengkritisi pemerintah. McKee pun meyakini bahwa konsep ruang publik dalam lingkup politik berguna untuk mengkritisi fungsi masyarakat demokratis (McKee 2009, 255). Hal itu sekaligus menunjukkan bahwa ruang publik memiliki peranan penting yang sekaligus sangat relevan dalam masyarakat demokratis, bukannya pada masyarakat feodalistis
(McKee 2009, 6). Pada kondisi inilah ruang publik berperan sebagai medium bagi rakyat dan negara untuk saling berinteraksi, penghubung antara opini publik dengan otoritas negara. Namun, realitas kemajemukan, khususnya kemajemukan budaya dan agama, memiliki tantangan yang dapat berubah menjadi masalah dengan dampak besar bagi proses komunikasi dalam ruang publik politis itu sendiri (Sumual et al., 2021).

Armando Salvatore menuliskan bahwa pola komunikasi dan nilai yang dimunculkan melalui komunikasi tersebut di dalam ruang publik telah menjadi cerminan dari iklim politik yang berkembang di dalam ruang publik politis (Salvatore 2007, 3). Kondisi yang paling sulit untuk dihadapi adalah ketika setiap identitas di dalam ruang publik muncul dengan mental untuk saling beradu atau bahkan berusaha untuk saling mendominasi identitas yang lainnya. Situasi tersebut akan semakin rumit ketika identitas telah menjadi bagian dari sebuah strategi politik. Itulah sebabnya, sejumlah akademisi politik tidak menyetujui 
adanya politik identitas di dalalm ruang publik.

Menurut Cressida Heyes, politik identitas merupakan sebuah frasa yang tidak memiliki bentuk tunggal dari situasi dan kondisi yang dapat menggambarkan atau mendefinisikan frasa tersebut. Namun, secara umum politik identitas adalah sebuah strategi politik dengan perencanaan yang masif dan terstruktur karena membutuhkan analisis tentang ketertindasan yang dialami oleh sebuah identitas kelompok, serta keragaman bentuk stigma yang diberikan kepada identitas tersebut sebagai dasar strategi politiknya (Heyes, 2016). Setiap pengalaman dari kelompok tersebut selalu bersifat partikular sehingga menjadikannya sebagai karakteristik dari politik identitas (Heyes, 2016). Artinya, setiap kelompok yang mengangkat identitasnya sebagai strategi politik mereka akan selalu berusaha menunjukkan partikularitas pengalamannya masing-masing.

Penggunaan kata 'identitas' pada frasa tersebut pun memiliki muatan filosofi yang menimbulkan perdebatan, yakni identitas seperti apa yang dimaksudkan melalui frasa tersebut. Heyes menggunakan beberapa pikiran para tokoh untuk mengkonstruksikan penjelasan tentang identitas di dalam politik identitas. Pertama, ia mengutip pemikiran Charles Taylor bahwa identitas modern merupakan hasil dari tekanan yang menetapkan sebuah otentisitas (Heyes, 2021). Hal tersebut dibuktikan melalui realitas kolonialisme yang berkembang pada masa modernisme, sebuah kebudayaan mencoba untuk mendominasi dan menghilangkan partikularitas kebudayaan lainnya. Oleh sebab itu, Sonia Kruks menuliskan bahwa muncullah kesadaran bahwa identitas yang 'dihilangkan' tersebut tidak kalah atau lebih rendah dari identitas lainnya (Heyes, 2021). Dasar dari argumen tersebut adalah setiap identitas memiliki keunikan (bersifat partikular) yang tidak dapat dipertarungkan dengan kebudayaan lainnya melainkan perlu berdampingan untuk saling menghargai (Heyes, 2021).

Tokoh lainnya yang memberikan definisi identitas adalah Manuel Castells yang berpendapat bahwa identitas adalah sumber makna dan pengalaman seseorang (Castells 
2010, 6). Pemaknaan tersebut didapatkan setelah terjadinya proses pembangunan identifikasi diri oleh masyarakat yang menghasilkan arti dan diinternalisasikan ke dalam identitas tersebut (Castells 2010, 7). Terdapat sebuah aspek yang sama di dalam penjelasan Heyes dan Castells tentang identitas, yaitu kesadaran. Kesadaran merupakan aspek yang sangat dibutuhkan untuk membentuk kerangka pengalaman sebuah kelompok identitas sebagai strategi politiknya. Hal itulah yang membuat sebuah politik identitas menjadi strategi yang partikular antara satu identitas dengan identitas lainnya (Heyes, 2021). Namun, penjelasan tersebut menunjukkan bahwa politik identitas sangatlah berisfat subjektif yang sekaligus dapat menjadi kelemahan bagi politik itu sendiri. Kritik itu jugalah yang diberikan oleh Kruks karena setiap politik identitas akan selalu berusaha mencapai tujuan politisnya dengan cara melegitimasi nilai-nilai yang mereka anggap benar melalui pengalamannya sendiri (Heyes, 2021).

Kritik tersebut sekaligus menunjukkan bahwa sebuah nilai yang diperjuangkan oleh kelompok tertentu melalui politik identitasnya bukanlah sebuah nilai yang pasti benar atau baik di tengah-tengah lingkungan komunitas yang lebih besar darinya, contohnya adalah sebuah negara. Selain itu, politik identitas juga dapat menciptakan pertengkaran nilai yang diperjuangkan oleh kelompok identitas lain melalui politik identitasnya. Hal ini semakin dikuatkan melalui realitas hibriditasidentitas pada era post-modernisme, dimana setiap identitas telah sedikitbanyak terpengaruh oleh identitas yang lainnya (Heyes, 2021). Apabila realitas tersebut tidak direspons dengan tepat dari setiap kelompok di dalam masyarakat tentu akan menimbulkan konflik yang berujung pada kondisi yang destruktif. Contohnya adalah tindakan genosida oleh Hitler bersama partai politik Nazi dengan menggunakan identitas bangsa Arya sebagai bangsa terkuat dan terhebat untuk melakukan pembantaian terhadap bangsa Yahudi.

Kemungkinan terjadinya konflik yang serupa semakin besar ditemukan pada negara yang memiliki keragaman bangsa yang 
DIEGESIS: Jurnal Teologi

Volume 6 No. 2, Agustus 2021.

besar. Hal ini disebabkan persaingan

nilai dari setiap bangsa dalam negara

tersebut yang berusaha untuk

mendominiasi bangsa lainnya melalui

nilai-nilai dalam politik identitas mereka masing-masing (Bertrand

2004, 6). Oleh sebab itu, menurut

Will Kymlicka sebuah negara yang memiliki keberagaman bangsa tidak akan bertahan tanpa adanya identitas bersama atau yang ia sebut sebagai 'identitas nasional', yaitu rasa keanggotaan dalam sebuah negara (Kimlycka 1995, 13).

Kemunculan identitas nasional juga semakin didorong melalui perkembangan globalisasi yang berujung pada hibriditas-identitas sehingga menuntut setiap individu serta kelompok masyarakat untuk berpikir melampaui batas identitasnya sendiri (Browning 2002, 280). Berdasarkan kesadaran itu jugalah muncul paham nasionalisme yang bertujuan menciptakan identitas

\footnotetext{
${ }^{1}$ Saya menggunakan kata 'modernisme' untuk merujuk keberadaan grand-narative atau dalam lingkup pembahasan tentang identitas adalah grand-identity, yakni sebuah identitas yang mendominasi identitas-identitas lainnya. Salah satu contoh grand-identity yang muncul pada masa modernisme adalah bangsa Arya dari Jerman yang berusaha untuk menaklukan Jerman dan sekitarnya dengan menggunakan politik identitas Arya ketika
}

nasional untuk bertindak demi mempertahankan negaranya. Gellner dan Giddens menyimpulkan bahwa akar kemunculan ideologi nasionalisme adalah permasalahan psikis identitas yang diakibatkan oleh modernisme $^{1}$. Namun, nasionalisme pun memiliki beragam deskripsi yang menghasilkan keragaman implementasi dari paham tersebut. Browning menyimpulkan bahwa nasionalisme, dengan beragam pengertian yang dimiliki, merupakan sebuah fenomena politik yang diekspresikan melalui beragam cara serta telah membuktikan pengaruhnya yang besar terhadap kehidupan politik dan sosial (Browning 2002, 281).

Kita pun perlu menghadapi maraknya tindakan politik identitas yang, berdasarkan beberapa kasus, justru menimbulkan permasalahan bagi proses di ruang publik. Secara khusus ketika identitas agama, yang

melakukan aksi pembantaian terhadap bangsa Yahudi. Inilah yang dilakukan oleh Hitler sebagai (samakan jenis huruf di catatan kaki dengan di tubuh makalah) politik identitasnya yang terbukti berhasil mendorong sebagian besar warga Jerman untuk terlibat dalam aksi genosida tersebut. Realitas itu juga telah mendorong kemunculan post-modernisme yang membuktikan bahwa tidak ada grandnarattive atau grand-identity. 
disandingkan dengan ideologi yang bersifat radikal-fundamentalis, telah dijadikan bagian dalam berkomunikasi di ruang publik politis. Topik tentang keberadaan agama di sebuah negara sebagai ruang publik politis, perlu dibahas dengan menggunakan sikap kritis dan rasional yang bermoral sehingga setiap umat beragama di dalam ruang tersebut tidak hanya sekadar menggunakan paham yang diterima begitu saja, entah berdasarkan dogma aliran agama, kelompok agamanya atau pernyataan langsung sang pemimpin agama tanpa disertai pemikiran maupun logika yang kritis.

Saya menganggap topik ini sangat perlu mendapatkan perhatian penuh dari para akademisi politik maupun agama di Indonesia. Hal tersebut berdasarkan kondisi ruang publik politis Indonesia masa sekarang yang dipenuhi dengan strategi politik identitas yang telah menghasilkan iklim perpecahan seperti pemaparan mengenai potret politik pada bagian sebelumnya. Secara khusus saya akan melakukan

\footnotetext{
${ }^{2}$ Pernyataan saya ini sekaligus menjadi batasan pengertian tentang gereja yang saya maksudkan dalam tulisan ini, yaitu gereja yang berisikan umat Kristen yang
}

penelaahan mengenai hubungan serta peran antara Kekristenan di Indonesia dengan negara.

Penginjilan salam Politik: Aksi Berteologi Misi dalam Ruang Publik Politis di Indonesia

Setiap warga negara ini memiliki peran untuk terlibat dalam negara atau ruang publik politis karena berpotensi untuk membangun sebuah kehidupan bersama yang lebih baik, meskipun juga berpotensi sebaliknya. Namun, hal tersebut hanya dapat diwujudkan apabila setiap warga negara terlibat dengan membawa pengetahuan yang tepat tentang kodrat manusia termasuk berelasi dengan sesama warga negara (Koten 2010, 135). Artinya, setiap warga negara ini perlu mendapatkan pembinaan atau persiapan agar mereka memiliki modal untuk menjadi agen-agen komunikasi yang memperjuangkan kebaikan bersama sebagai sebuah komunitas politik. Hal ini juga berlaku bagi gereja dimana setiap individu yang ada di dalamnya merupakan bagian sekaligus warga negara dimana mereka berada ${ }^{2}$.

berstatus sebagai Warga Negara Indonesia (WNI). Artinya, saya tidak melakukan penelaahan mengenai peran gereja yang berisikan para ekspatriat atau warga negara 
Namun, Koten pun mengkritik realitas sosial politik di Indonesia yang menurutnya justru telah menunjukkan kemunduran moral dan rasional telah menjadi medan perebutan kepentingan (Koten 2010, 228). Memang kritik yang diberikan oleh Koten lebih ditekankan kepada insitusi negara yang menurutnya tidak lagi menjalankan fungsinya sebagaimana mestinya polis berfungsi. Saya menganggap bahwa kritik itu adalah penting dan perlu terus diberikan atau dibentuk oleh para warga negara agar tidak terjebak dalam kehidupan yang diterima begitu saja demi menjadi publik yang kritis, rasional dan bermoral di dalam ruang publik politis. Artinya, para warga negara perlu dipersiapkan untuk mampu menghasilkan proses komunikasi yang konstruktif bagi kehidupan bersama. Pada tahap inilah saya menganggap gereja dapat melakukan perannya dalam mempersiapkan anggotanya untuk tampil dan berperan sebagai individu yang partisipatif-konstruktif dalam ruang publik politis.

asing yang sekedar datang berlibur atau bekerja di Indonesia. Pembatasan ini saya lakukan karena terkait dengan beban moral dan politik dari gereja yang lebih besar
Pertanyaan yang muncul ketika membahas partisipasi gereja (agama) dalam ruang publik, dalam hal ini politik, adalah perlukah agama menjadi bagian dari ruang publik? Setidaknya pertanyaan ini jugalah yang menjadi dasar penulisan buku Religion in Public Life: Must Faith be Privatized? karya Roger Trigg. Konteks Eropa dan Amerika Utara yang telah dilanda gelombang sekularisasi besar-besaran telah menyingkirkan peran agama ke dalam ruang yang sangat privat sehingga agama semakin kehilangan tempat dalam ruang publik (Trigg 2007, 190). Kondisi inilah yang disebut sebagai privatisasi agama. Saya lebih menganggapnya sebagai sinisme terhadap agama dalam ruang publik, entah itu karena agama dianggap menjadi penghambat atau tidak berguna bagi proses di ruang publik. Kritik mengenai perlu atau tidaknya agama hadir dalam ruang publik menjadi sebuah pertanyaan yang juga relevan untuk didiskusikan dalam konteks Indonesia dengan pluralitas yang tinggi, namun disertai

dimiliki oleh gereja dengan WNI sebagai anggotanya dibandingkan gereja yang berisikan Warga Negara Asing. 
kondisi politik yang tidak kondusif, termasuk terkait kehadiran agama dalam ruang publik politis.

Ahmad Nurcholis menganggap bahwa sinisme terhadap agama perlu disikapi dengan kritis. Pandangan pesimis dan sinis dari sejumlah orang terhadap kehadiran agama dalam ruang publik memang tidak dapat disalahkan sekaligus tidak dapat diterima begitu saja. Dalam kerangka berpikir Nurcholis sikap pesimisme dan sinisme terhadap agama, kerap muncul karena wajah agama yang ditampilkan dalam ruang publik telah mengambil wujud yang menyeramkan, mengganggu hingga menimbulkan 'bencana' dalam ruang publik. Hal yang perlu segera dilakukan bukannya meninggalkan dan menyempitkan ruang agama ke dalam ruang privasi, melainkan melakukan transformasi wajah agama menjadi bercorak humanis (Nurcholis 2017, 13). Transformasi wajah agama sangat berdampak bagi penerimaan dan peran agama di ruang publik, terlebih lagi ketika agama itu hadir di dalam sebuah ruang publik yang pluralis seperti Indonesia (Setyobekti et al., 2021). Itulah sebabnya sebagai salah seorang pemikir-religius
Indonesia, Nurcholis menawarkan untuk melakukan sebuah transformasi wajah agama yang saling mengenal secara intim, menebar kasih sayang, toleran dan menghadirkan perdamaian di dalam pluralitas Indonesia (Nurcholis 2017, 13). Hal ini perlu dilakukan agar agama tidak kehilangan perannya dalam ruang publik. Sekaligus, agama menurut Nurcholis dapat berperan untuk memberikan kewaspadaan bagi pemeluknya untuk memberikan perlawanan terhadap setiap gerakan atau semangat anti perdamaian dalam pluralitas bangsa ini.

Persoalannya sekarang adalah sikap acuh dari para individu terkait persoalan agama dalam ruang publiklah. Inilah yang menjadi kritik dari Nurcholis mengenai perilaku manusia beragama berdasarkan fenomena pengalaman yang ia dapatkan ketika salah seorang Muslim yang ia kenal justru membagikannya cerita tentang perilaku salah seorang Muslim lainnya yang menyetujui dan bersemangat dalam aksi terorisme dengan menggunakan wajah agama, namun dibiarkan begitu saja oleh orang yang mengenalnya meski tidak 
sependapat dengan orang tersebut. Menurut saya, pengalaman yang Nurcholis bagikan tersebut telah menjadi sebuah fenomena bagaimana manusia beragama justru bersikap tidak jelas dan tidak tegas tentang penempatan agama di ruang publik. Bahkan, kondisi semacam itu dapat mencerminkan adanya misorientasi tentang penggunaan identitas agama di dalam ruang publik, termasuk disorientasi dalam memandang dan memaknai ruang publik Indonesia itu sendiri. Lantas sekarang, apakah agama perlu diprivatisasi?

Privasi memang sebuah kebutuhan individu karena segala hal tidak dapat menjadi konsumsi publik dan segala hal pribadi tidak dapat dijadikan sebagai beban publik atau kepentingan publik (McKee 2005, 34). Setiap orang tentu memiliki aspek publik, yakni perannya sebagai masyarakat yang menjadikannya tidak dapat memprivatisasi diri dan segala hal yang berkaitan dengan dirinya, termasuk agama. Hal ini berlaku dalam model masyarakat yang demokratis, namun sekali lagi tidak dalam masyarakat yang feodalistis karena agama cenderung mengatur setiap aspek kehidupan termasuk ruang privasi setiap individu di dalam negara tersebut. Namun, di dalam masyarkat demokratis agama justru memiliki kesempatan untuk berperan di dalam ruang publik. Agama, menurut Trigg, dalam banyak bentuk dapat mengembangkan dan memberikan pengaruhnya tidak hanya di dalam ruang pribadi tetapi juga dalam ruang publik (Trigg 2007, 9). Hal ini pun berlaku bagi keberadaan gereja.

Keterlibatan gereja di dalam ruang publik politik tentu membutuhkan karya nyata yang ditujukan, memberikan perhatian dan dapat dinikmati oleh publik. Hal ini tentu membutuhkan dasar teologi yang mampu mempersiapkan dirinya untuk bersikap dan berpartisipasi dalam ruang publik politik. Inilah yang disebut sebagai teologi politik. Jurgen Moltmann menuliskan bahwa teolog politik merupakan bentuk teologi Kristen yang bersikap kritis terhadap kondisi dan permasalahan politik (Moltmann 1974, 21). Teologi politik ini pun berawal dan bersumber dari aksi penyelamatan Yesus melalui kayu salib yang sangat politis. Moltman menuliskan, "Christian faith and theology have their origin in the political crucifixion of Christ and have fought the political religious of 
peoples and states." (Moltmann 1974, 21). Salib menjadi simbol karya penyelamatan Yesus yang harus mati melalui strategi politis yang dibuat dan dijalan oleh beragam aktor-aktor religius-politis pada saat itu. Namun, salib juga menunjukan ketulusan aksi penyelamatan Yesus, yang meskipun menjadi korban para pemegang otoritas politik pada masa itu, justru rela menerima kematian dalam cara politik tersebut untuk memberikan penyelamatan bagi manusia termasuk yang membunuh-Nya, bukan untuk diri-Nya sendiri.

Namun, kematian Yesus di kayu salib sekaligus menjadi titik awal kemunculan sikap kritis untuk menggugat batasan kuasa dan tujuan dari politik negara. Aksi penyelamatan Yesus melalui kayu salib telah menjadi simbol perlawanan terhadap kuasa politik sekaligus terhadap sikap status quo terhadap otoritas politik, yang sejak sebelum peristiwa penyaliban Yesus, merupakan sikap yang cenderung dipertahanakan dan dikembangbiakan dalam ruang publik. Inilah yang menjadi dasar teologi politik bagi gereja untuk menghadirkan dirinya di dalam ruang publik sebagai institusi yang berupaya untuk mewujudkan pembebasan kritik sosial (Moltmann 1974, 40). Sehingga batasan atau tembok tebal perbedaan dapat diruntuhkan (Untung, 2017).

Bagi Julianus Mojau keterlibatan gereja dalam ruang publik merupakan bagian dari eklesiologi sebagai tubuh Kristus dan umat Allah di dunia ini. Agama perlu dan suka-tidak-suka memiliki keharusan teologis tersendiri untuk menjalin interaksi dengan dunia sekitarnya, termasuk dunia politik (Moltmann 1974, 41).

Tidak ada sebuah penghalang teologis bagi gereja untuk menarik dirinya dari ruang publik politis karena Allah itu sendiri berifat politis (Mojau 2009, 83). Oleh sebab itu, bentuk pengabdian gereja dalam ruang publik adalah dengan melibatkan dirinya di dalam ruang publik. Keterlibatannya di dalam ruang publik politis juga memberikan kesempatan bagi gereja-gereja, khususnya di Indonesia, untuk menjadi komunitas iman yang memberdayakan dan terbuka-dialogis ketika menghadapi pluralitas (Mojau 2009, 84). 
Stephen B. Bevans dan Roger

P. Schroeder juga dapat menolong kita untuk semakin menyadari nilai kehadiran gereja dalam perspektif misiologis di ruang publik politis. Bevans dan Schroder menawarkan misi sebagai dialog profetis. Nilai dialogis telah memberikan gereja kesempatan sekaligus tanggungjawab untuk menjalin komunikasi yang terbuka dengan tradisi, kebudayaan dan pengalaman sebagai respons misi gereja dan nilai propetis telah menjadikan gereja untuk berperan untuk memanggil orangorang melampaui realitas melalui kebenaran yang gereja tampilkan (Bevans \& Schroder 2004, 285). Keterlibatan gereja di dalam ruang publik politis sebagai misi gereja semakin perlu dilakukan karena di dalam proses politik terdapat kairos yang berpotensi untuk mengubah kondisi sosial, seperti kesejahteraan dan merespons kemiskinan (Mojau 2009, 84).

\section{Keterlibatan tersebut} merupakan tanggung-jawab politis gereja-gereja di Indonesia untuk merespons permasalahanpermasalahan politik dengan tujuan pemberdayaan. Inilah tawaran Mojau bagi gereja-gereja di Indonesia, yaitu politik pemberdayaan untuk berpartisipasi dalam ruang publik politis (Mojau 2009, 84).

Persoalannya adalah masih banyak gereja yang cenderung enggan untuk berteologi dalam ranah politik di ruang publik. Padahal sejatinya teologi sangat berpengaruh pada kesiapan umatnya menghadapi perubahan-perubahan politik serta sosial dan gereja adalah agen yang berperan untuk memberikan strategistrategi teologis terhadap kondisi tersebut.

Julianus Mojau pun berpendapat bahwa interaksi antara gereja dengan dunia politik merupakan sebuah keharusan tersendiri yang sangat terkait dengan iman Kristen kepada Allah dalam Yesus Kristus (Mojau 2009, 83). Politik memiliki kairos untuk terciptanya sebuah transformasi kondisi sosial yang artinya gereja pun perlu memberikan peranan politiknya demi mewujudkan hal tersebut.

Sayangnya masih banyak gereja yang tidak mau memahami gereja sebagai komunitas iman politis sehingga gereja justru tampil di dalam ruang publik dengan sikap yang cenderung tidak peduli dengan masalah-masalah sosial yang bersifat 
politis (Mojau 2009, 85). Anggapan tersebut memang bukanlah tanpa sebab. Apabila kita melakukan kilasbalik historis yang lebih jauh lagi untuk memahami faktor lain mengapa umat Kristen di Indonesia membangun batas untuk terlibat dalam politik-praktis, maka tulisan Ayub Ranoh pun dapat kita jadikan materi reflektif. Menurut Ranoh kita perlu mengakui bahwa gereja berkembang di Indonesia sejak masa Kolonialisme dan hubungan antara gereja dengan negara pada masa itu merupakan bagian dari politik negara (Ranoh 2009, 126). Kondisi itu mengakibatkan gereja kehilangan sikap kritis dan propetisnya dalam ruang publik. Memasuki masa kemerdekaan bangsa Indonesia, Kekristenan di dalamnya pun mulai memberikan perhatiannya mengenai kegiatan politik yang juga dipengaruhi kemunculan gerakan ekumenis gereja dalam lingkup dunia (pembentukan Dewan Gereja seDunia) dan nasional (pembentukan Dewan Gereja-gereja di Indonesia). Sejak awal DGI telah memahami bahwa masalah politik dan kekuasaan merupakan agenda ekumenis di Indonesia (Ranoh 2009, 127).
Pada era Demokrasi Terpimpin, DGI berdasarkan hasil Konferensi Gereja dan Masyarakat tahun 1962 mengakui bahwa gereja perlu bersifat kritis, positif, kreatif dan realistis dalam lingkup pelayanan sosial dan politik (Ranoh 2009, 131). Namun, tumbangnya kepemimpinanSoekarno telah membawa mereka kepada model berpikir yang baru. Peralihan pemerintahan disikapi oleh DGI bahwa Orde Baru dipahami sebagai kerajaan Allah yang sekaligus merupakan bagian dari pelayanan gereja. Tema kekuasaan politik pun mendapatkan perhatian dari teologi gereja para Orde Baru sehingga menimbulkan fenomena keterlibatan sejumlah orang Kristen dalam politik praktis yang tanpa agenda misi ekumenis justru membuat gereja menjadi 'anak emas' Orde Baru sehingga mengurangi pengaruh bagi perpolitikan di Indonesia (Ranoh 2009, 136).

Sejak saat itu, gereja hidup dalam sangkar 'Orde Baru' yang meskipun telah beralih ke eraReformasi ternyata tetap kurang memiliki suara propetis dan kritis terhadap isu sosial-politik. Pemaparan historis-reflektif oleh 
Ranoh tersebut telah menunjukkan perjalanan pandangan dan sikap teologis-politis gereja di Indonesia yang justru bermuara pada sikap pasif. Padahal, gereja dapat menggunakan bidang politik-praktis sebagai bentuk eksistenisalnya dengan menggunakan pendekatan yang menjunjung tinggi kekritisan historis dan sosiologis gereja di dalam ruang publik (Soelee 1974, 52).

Kesadaran gereja yang tidak perlu terlibat dalam ruang publik politis bagi Mojau merupakan sebuah kesadaran teologis yang palsu. Kesadaran palsu tersebut justru mendorong umat Kristen untuk tampil dengan sikap yang diskriminatif dan tidak siap merespons kemajemukan di Indonesia dengan sebuah sikap yang terbuka, sebagaimana teologi misi yang Bevans dan Schroder tawarkan.

Wujud utama dari teologi diskriminatif dalam ruang publik adalah ketika seorang yang beriman dan/atau komunitas iman tertentu selalu mengalami gangguan mental fobia, paranoid, dan reaksioner yang selalu curiga dengan setiap orang atau kelompok yang berbeda dari dirinya serta akan dianggap sebagai ancaman, bukannya sebagai pewahyuan wajah
“Sang Liyan" sejati (Mojau 2009, 25). Inilah dasar teologis yang menurut saya juga memupuk kultur beragama yang radikal-fundamentalis di dalam ruang publik, termasuk politik.

Teologi diskriminatif akan selalu berupaya, entah itu melalui strategi misi maupun politik, melakukan dominasi terhadap pihak lainnya yang berbeda dari dirinya. Kondisi ini juga muncul dalam teologi misi Kristenisasi yang berusaha untuk menyeragamkan umat beragama lain.

Semangat menyeragamkan itu telah menjadi sebuah politik identitas yang mau menampilkan diri atau/dan kelompoknya sebagai pemegang supremasi dalam pertemuan di ruang publik. Tentu saja itu bukanlah sebuah semangat yang dialogis, yang terbuka dan siap untuk bekerjasama dalam pembangunan opini publik serta tidak layak untuk dianggap sebagai persiapan dari gereja bagi umat untuk terlibat dalam ruang publik politis.

Alih-alih menyampaikan Injil ke seluruh dunia, mentalitas beragama yang narsistikfundamentalis dalam paham Kristenisasi justru telah membentuk 
wajah yang menakutkan tentang Kekristenan di dalam ruang publik. Dampaknya, telah terjadi sebuah disorientasi pandangan dari nonKristen terhadap Kekristenan di dalam ruang publik, seolah-olah kehadiran umat Kristen di dalam ruang publik berupaya untuk melekukan supremasi terhadap diri mereka. Hal ini tentu bukanlah sebuah kondisi yang baik sekaligus telah mempersempit tempat bagi gereja untuk hadir dalam ruang publik, secara khusus politik. Kecenderungan pemahaman yang akan muncul pada non-Kristen adalah gereja (umat Kristen) yang hadir dalam pentas politik sedang berupaya mendapatkan kekuasaaan politik untuk melakukan dominasi politis terhadap non-Kristen.

Bryan Stone memiliki pengalaman yang menimbulkan kesadaran kritis pada dirinya utnuk merekonstruksi teologi penginjilan pada masa sekarang. Stone menyadari bahwa realitasnya evangelisme telah menjadi momok yang menakutkan atau setidaknya tidak indah pada masa kini. Secara khusus ketika kata tersebut ditampilkan pada konteks inter-religius atau kebudayaan yang majemuk, justru dianggap sebagai penghalang atau intoleransi bahkan superioritas terhadap pihak selain Kekristenan. Padahal evangelisasi pada dasarnya bermakna memberikan 'kabar baik' atau sebuah 'pesan sambutan' berdasarkan Yesaya 52:7 (Stone 2009, 9).

Mojau meyakini bahwa gereja memiliki potensi kekuatan sosial politis yang memberdayakan rakyat (Mojau 2009, 100). Pandangan bahwa gereja tidak perlu terlibat dalam kegiatan politik perlu ditinggalkan dan beralih kepada kesadaran bahwa gereja dapat berperan politis sebagai upaya untuk memberdayakan warga jemaat dan warga masyarakat (Mojau 2009, 86). Tindakan realistis yang dapat gereja wujudkan dalam lingkup sosial adalah menjadi komunitas sosial yang demokratis dan komunikatif untuk mewujudkan proses emansipasi dan liberasi (Mojau 2009, 119).

Demokratis dan komunikatif pun menjadi dua karakter dari tindakan misional umat Kristen dalam masyarakat yang perlu mendapatkan perhatian dari setiap umat yang hadir di dalam ruang 
publik, termasuk dalam kegiatan politik praktis.

Namun, potensi tersebut bukan ditujukan agar gereja mendapatkan kekuasaan dalam politik praktis melainkan sebagai upaya pedagogis dan pendampingan dalam proses pemberdayaan bagi rakyat, khususnya umat Kristen, agar memiliki kecerdasan politis yang kritis (Mojau 2009, 101). Politik pemberdayaan juga merupakan wujud dari teologi politik salib yang Yesus teladankan. Salib Yesus telah menjadi simbol bahwa kematian Yesus merupakan tindakan politis Allah yang memberdayakan kemanusiaan dengan pengorbanan Diri-Nya sendiri.

Pemahaman teologis Stone juga selaras dengan kesadaran teologis politis milik Mojau, bahwa kehadiran gereja dalam ruang publik adalah sebuah tanggung-jawab dan kebutuhan karena peran gereja yang fundamental sebagai agen teologi dan sosiologis yang bertanggung-jawab untuk menghadirkan transformasi personal dan sosial (Stone 2009, 20). Inilah penginjilan yang perlu gereja lakukan di masa sekarang, khususnya di tengah konteks yang pluralis, yaitu menjadi dan menjalankan perannya yang fundamental tersebut. Gereja adalah agen teologis dan sosiologis sehingga gereja perlu untuk terlibat dalam ruang publik politis.

Namun, kehadiran gereja sebagai komunitas yang melakukan penginjilan tersebut di dalam ruang publik telah menuntut gereja untuk melepaskan dirinya dari sikap mendominasi dan keenganan untuk berdialog dengan orang lain agar penginjilan yang gereja lakukan menjadi sebuah aksi yang nyata dan aktif.

Penginjilan dalam ruang publik politis merupakan sebuah bagian dari identitas penginjilan itu sendiri karena penginjilan juga merupakan bagian politik yang membutuhkan proses, aturan dan kemampuan untuk menghadirkan pemerintahan Allah yang penuh dengan kedamaian. Namun, hal tersebut bukan berarti gereja menjadi aktor politik yang mendominasi dunia. Justru, penginjilan dalam ruang publik politis sebagai praktek untuk memberikan kesaksian tentang kedamaian Allah perlu terus dipraktekan meskipun praktek itu sendiri mengalami penolakan dari lingkungan sekitar ia muncul (Stone 2009, 223). 


\section{Menghindar atau Menghadirkan} Diri?

Gereja-gereja di Indonesia sudah tidak dapat lagi bersikap mautak-mau dalam menghadapi isu-isu politik. Bahkan, bagi saya, keterlibatan gereja di dalam politik adalah sebuah keharusan. Hal ini merupakan sebuah kesimpulan sederhana terhadap pernyataan saya pada bagian awal, bahwa keterlibatan gereja di dalam politik merupakan eksistensi gereja sekaligus wujud penginjilan gereja pada masa sekarang.

Seluruh umat Kristen perlu menyadari bahwa sebagai komunitas iman yang telah diberdayakan oleh Allah, mereka juga memiliki tanggung-jawab sekaligus potensi pemberdayaan yang mampu melakukan perubahan dalam setiap aspek kehidupan di mana mereka hadir. Artinya, keberadaan setiap umat Kristen di dalam ruang kehidupannya perlu dipandang denga optimisme bahwa mereka adalah agen-agen perubahan termasuk membawa perubadah konstruktif dalam ruang publik politik.

Gereja perlu melakukan pedagogi yang dialogis dengan umat sebagai tindakan pembentukan misinya di dunia ini. Gereja tidak boleh tidak mengambil tempat dalam ruang publik yang ada. Gereja perlu melakukan pembinaan teologis yang dimulai dari umat Kristen sehingga muncul kesadaran politis yang cerdas, kritis dan bermoral. Hal tersebut sangat berguna agar kehadiran mereka di dalam ruang publik politis mampu menghasilkan pilihan-pilihan yang menghasilkan perubahan.

Bahkan, mereka juga dapat terlibat dalam pembentukan kebijakan, peraturan dan pelaksanaan kegiatan politik praktis yang lebih menjunjung tinggi kekeluargaan dan kesejahteraan sosial bukannya kelompok tertentu, termasuk Kekristenan di Indonesia itu sendiri.

Selain itu, keterlibatan gereja, melalui umat, di dalam ruang publik politis dengan memperhatikan nilainilai penginjilan dan profetisnya dalam kemajemukan Indonesia perlu diwujudkan agar gereja tidak menjadi 'parasit' masyarakat. Kritik yang diberikan Julianus Mojau mengenai ketidakjelasan gereja di Indonesia ketika merespons persoalanpersoalan politik praktis, bagi saya, telah menunjukkan sebuah ciri gereja 
yang hanya taken for granted. Gereja yang seperti itu hanya menunjukkan dirinya telah kehilangan sikap kritis, rasional, moralitas dan peran profetisnya sebagai peninjil. Apa artinya kalau bukan sekadar menumpang hidup dan tidak memberikan dampak konstruktif apapun bagi bangsa ini. Malahan gereja, layaknya dampak parasit pada sebuah inang, hanya akan menjadi penyakit melalui sikap non-kritis akibat ketidakjelasan pengambilan peran dan sikapnya dalam politik.

Gereja perlu menjadi organik dalam ruang publik melalui pemenuhan peran profetismenya di dalam ruang publik politis jika ia mau tetap mempertahankan karakter misional yang ada pada dirinya. Inilah bentuk nyata gereja yang menjadi bagian hidup atau organ dari bangsa.

Gereja sebagai organ bangsa berarti akan ikut merasakan sakit jika ada penyakit yang menyerang tubuhnya. Kemudian, selayaknya tubuh yang berusaha meningkatkan antibodi untuk melawan penyakit itu, gereja pun perlu menjadi bagian dari tubuh (baca: bangsa) yang meningkatkan antibodi dalam melawan penyakit-penyakit yang menggerogoti bangsa.

Selain itu, keterlibatan yang aktif dari gereja dalam ruang publik politis dapat menjadi wujud gereja yang bermisi, menjalankan penginjilannya secara profetisdialogis. Gereja dapat menjadi sangat kontekstual untuk meningkatkan serta menyuarakan sikap kritisnya terhadap kondisi keadilan sosial, perekonomian dan persoalan politik lainnya di dalam dan sesuai konteksnya masing-masing (Pakpahan, 2021).

Namun, keterlibatan itu perlu diimbangi dengan kesadaran bahwa dirinya bukan bermaksud untuk menjadi par excellence dibandingkan organ bangsa yang lain, secara khusus agama-agama yang ada di Indonesia. Melainkan dilaksanakan dengan kesadaran untuk menjalankan perannya sebagai agen teologis dan sosial yang bermisi dengan menggunakan kairos yang ada dalam setiap proses komunikasi di dalam ruang publik politis, termasuk pertemuannya dengan agama-agama lain, untuk meningkatkan kualitas hidup berbangsa dan bernegara.

Gereja yang menarik diri dari ruang publik politik hanya menjadi 
upaya penolakan identitas dan hakikatnya sendiri. Malahan, gereja yang menjaga jarak, bahkan enggan untuk terlibat dalam ruang publik politik hanya akan semakin memberi kesempatan bagi para aktor politik yang mencari kekuasaan politik untuk kepentingannya dan golongannya sendiri untuk menggunakan agama sebagai kendaraan politiknya. Hal itu berarti agama hanya akan menjadi objek dalam ruang publik politik. Agama tidak lagi memiliki kemampuan untuk bersuara secara politis dan agama juga tidak memiliki kesempatan untuk melakukan perubahan dalam ruang publik politis.

Padahal, melalui politiklah gereja dapat berperan besar dalam gerakan pembangunan perdamaian negara. Melalui politiklah gereja dapat melakukan upaya pembebasan kaum miskin melalui penumbuhan kesadaran untuk menciptakan peraturan-peraturan yang tidak menekan sekelompok manusia yang tertindak dalam budaya industri. Melalui politik jugalah gereja dapat melakukan kritik terhadap para penguasa yang sudah semakin meninggalkan tujuan peningkatan kualitas hidup bersama.

\section{KESIMPULAN}

Urgensi keterlibatan gereja dalam ruang publik politis tidak dapat ditunda, melainkan sudah menjadi sebuah tuntutan yang tidak dapat dihindari untuk dilakukan pada masa sekarang. Gereja perlu menyadarkan dirinya sendiri bahwa dia adalah agen teologis dan sosial. Kedua aspek tersebut merupakan bagian dari hakikat gereja yang mesti nampak dalam setiap aspek kehidupannya sehingga gereja menjadi bagian yang 'hidup' dari negara, dalam hal ini Indonesia.

Maksud saya, gereja sebagai bagian organisme dalam masyarakat Indonesia perlu hidup dan menghidupi masyarakat itu sendiri. Salah satu caranya adalah melalui keterlibatan umat dalam ruang publik politis. Inilah yang saya sebut sebagai keterlibatan gereja dalam ruang publik politik, yakni ketika umat Kristen, khususnya yang merasa terpanggil untuk berpartisipasi aktif dalam ruang publik politik, telah mengalami pendidikan misional dengan landasan teologis yang memampukan ia untuk hadir secara 
bertanggung-jawab dan responsif di ruang publik politik.

\section{DAFTAR PUSTAKA}

Bertrand, Jacques. 2004. Nationalism and Ethnic Conflict in Indonesia. Cambridge: Cambridge University Press.

Bevans, Stephen B. dan Roger P. Schroder. 2004. Constans in Context: A theology of Mission for today. Maryknoll: Orbis Books.

Browning, Gary K. 2002. Politics: An Introduction. Madison Ave: Routledge.

Chandra, D. C. (2019). FUNGSI TEORI DALAM METODE PENELITIAN KUALITATIF. Reseach Gate.

Pakpahan, G. K. R. (2021). MEMBANGUN

SOLIDARITAS

KEMANUSIAAN: KRITIK NABI AMOS TERHADAP PRAKTIK PELANGGARAN HAK ASASI MANUSIA. Manna Rafflesia, 7(2), 441-466.

Setyobekti, A. B., Kathryn, S., \& Sumen, S. (2021). Implementasi Nilai-nilai Bhineka Tunggal Ika dalam Membingkai Keberagaman Pejabat Gereja Bethel Indonesia di DKI Jakarta. SOTIRIA (Jurnal Theologia Dan Pendidikan Agama Kristen), 4(1), 1-10. https://doi.org/10.47166/sot.v4i 1.29

Sumual, I. S., Hasudunga, L., Abdillah, A., \& Edu, F. (2021). Peran dan Kerjasama Gereja Bethel Indonesia Torsina dengan Pemerintah dalam Mensejahterakan Masyarakat di daerah Olafuliha' a, Pantai Baru
, Rote Ndao: Implementasi Roma 13:1-7. LOGON ZOES: Jurnal Teologi, Sosial Dan Budaya, 4(2), 1-7.

Trisna, R. P. (2016). Peranan Orang Kristen dalam Kehidupan Bernegara. In Bergereja dalam Bingkai Kebangsaan. STT Bethel Indonesia.

Untung, N. (2017). Kristus dan Perempuan Samaria: Yohanes 4:1-42. In Misi Inklusif: Berjumpa dengan Firman dan Realitas untuk Misi yang Inklusif (p. 96). STT Bethel Indonesia.

Castells, Manuel. 2010. The Power of Identity. West Sussex: WileyBlackwell.

Cressida Heyes. "Identity Politics," https://plato.stanford.edu/entrie s/identity-politics/ (diakses 20 Februari 2021).

Dorothee, Soelle. 1974. Political theology. Philadelphia: Fortress press.

Habermas, Jurgen "The public sphere" dalam Contemporary Political Philosophy: An anthology, peny. Robert E. Gooding \& Philip Pettit. Canberra: Blackwell Publishers, 1997.

Kimlycka, Will. 1995. Multicultural Citizenship: a Liberal Theory of Minority Rights. Oxford: Clarendon Press.

Koten, Yosef Keladu. 2010. Partisipasi Politik: Sebuah analisis atas etika politik Aristoteles. Yogyakarta: Penerbit Ledalero.

McKee, Alan. 2005. The Public Sphere: An introduction. Cambridge: Cambridge University Press.

Moltmann, Jurgen. 1974. Religion and political society. New 
York: Harper \& Row Publishers.

Mojau, Julianus. 2009. Teologi Politik Pemberdayaan.

Yogyakarta: Penerbit Kanisius.

Nurcholis, Ahmad. 2017. Merajut

Damai dalam Kebinekaan.

Jakarta: Kompas Gramedia.

Ranoh, Ayub. "Kristen dan Politik di Indonesia: Refleksi Historis." dalam Teologi politik: Agamaagama kekuasaan, peny. Einar M. Sitompul. Jakarta: Badan Penelitian dan Pengembangan Persekutuan Gereja-gereja di Indonesia dan Mission 21, 2009.

Salvatore, Armando. 2007. The Public Sphere: Liberal Modernity, Catholicism, Islam. Macmillan: Palgrave.

Samosir, Leonardus "Persatuan Indonesia: Unitas dalam Pluralitas." dalam Perjumpaan Pancasila dan Kristianitas: Reposisi relasi negara dan agama dalam masyarakat plural, peny. Mateus Mali, 253264. Yogyakarta: Penerbit Lemalero \& Jakarta: Komisi Teologi KWI, 2009.

Stone, Bryan. 2007. Evangelism after Christendom: the theology and practice of Christian witness. Grand Rapids: Brazos Press.

Trig, Roger. 2007. Religion in Public Faith: Must Faith be Privatized?. New York: Oxford University Press. 